\title{
Incivility and disrespectfulness in online political discussion
}

\section{Ketidakberadaban dan ketidaksopanan dalam diskusi politik daring}

\author{
Angga Prawadika Aji ${ }^{* *} \&$ Ari Sapto ${ }^{2}$ \\ ${ }^{1}$ Department of Communication, Faculty of Social and Political Sciences, Universitas Airlangga \\ ${ }^{2}$ Department of History, Faculty of Sosial Sciences, Universitas Negeri Malang \\ Address: ${ }^{1}$ Jalan Dharmawangsa Dalam, Airlangga, Surabaya, East Java 60286 \\ ${ }^{2}$ Jalan Semarang, Lowokwaru, Malang, East Java 65145 \\ E-mail: angga.prawadika@fisip.unair.ac.id* \& ari.sapto.fis@um.ac.id
}

Article History: Received 7 November 2019; Accepted 4 August 2020; Published Online 30 August 2020

\begin{abstract}
Reader's comment columns on online political news pages are locations where political discussions between citizens can emerge and develop. The reader comment column is a standard feature of almost all media sites because of its ability to initiate discussion and promote a particular article or issues within the news site. Unfortunately, in its development, the online comment column's discussion process is often filled by incivility and disrespectful expressions, such as sentences containing insults, condemnation, or expressions full of anger. Such sentences have the potential to undermine the discussion process and encourage pointless arguments, especially in articles that discuss political polarity. This study aims to determine the extent to which incivility and disrespectful expressions appear in readers' comments columns of online news sites, especially on polarized political issues. This study uses content analysis techniques on 403 comments in political news on Detik. com, one of Indonesia's main news portals. The results show that although the incivility expression shows a small number, the form of disrespectful shows a high number in the readers' comments. The highest form of the expression of disrespectful is the expression tat contains name-calling (23\%), followed by hyperbole $(15.6 \%)$ and the use of sarcasm $(6.2 \%)$. The high number of disrespectful expressions seems to be related to the comment column service feature that allows users to use anonymous identities.
\end{abstract}

Keywords: incivility; disrespectfulness; online political discussion; flaming; content analysis

\begin{abstract}
Abstrak
Kolom komentar pembaca dalam laman berita politik daring adalah salah satu lokasi dimana diskusi politik antar warga negara dapat muncul dan berkembang. Kolom komentar pembaca menjadi sebuah fitur standard dimiliki hampir semua situs media karena kemampuannya untuk menginisiasi diskusi dan perhatian terhadap artikel tertentu. Sayangnya, dalam perkembangannya proses diskusi dalam kolom komentar daring seringkali diwarnai oleh ekspresi yang tidak beradab dan tidak sopan, seperti kalimat yang berisi penghinaan, umpatan, maupun ungkapan yang penuh kemarahan. Kalimat-kalimat semacam ini berpotensi besar merusak proses diskusi serta mendorong pertikaian, terutama dalam artikel yang membahas polaritas politik. Penelitian ini bertujuan untuk melihat sejauh mana ekspresi tidak beradab dan tidak sopan muncul dalam kolom komentar pembaca situs berita daring, terutama pada isu politikyang terpolarisasi. Studi ini menggunakan teknik analisis isi pada 403 komentar dalam berita politik di Detik.com, salah satu portal berita utama di Indonesia. Hasil penelitian menunjukkan walaupun ekspresi ketidakberadaban menunjukkan angka kecil, namun bentuk ekspresi ketidaksopanan menunjukkan angka yang tinggi dalam komentar pembaca. Bentuk ekspresi ketidaksopanan yang paling tinggi ialah bentuk ekspresi memanggil dengan hinaan (23\%) dilanjutkan dengan penggunaan hiperbola (15,6\%) dan penggunaan sarkasme (6,2\%). Tingginya angka ekspresi ketidaksopanan ini nampaknya berkaitan denganfitur layanan kolom komentaryangmemperbolehkan penggunamenggunakanidentitas anonim.
\end{abstract}

Kata kunci: ketidakberadaban; ketidaksopanan; diskusi politik; flaming; analisis isi

\section{Introduction}

The exchange of ideas in the form of political discussion has long been understood as a vital part of a democratic society. Only through political discussions can the community members clarify their views, learn about others' opinions, and find the main problems that society faces as a collective 
(Rowe 2014). Through this process of discussion, citizens can truly understand a particular issue, tie it into their pre-existing knowledge, and ultimately engage in meaningful participation in political life (Schaufele 2001). This ability of the internet to construct more active political discussion, a discussion that is more open to all circles and layers of society, signals this medium's ability to act as a location to form a more definitive version of the public sphere and there is one challenging issue faced by the previous notion. There is a growing concern that the character of communication on the internet often appears to be nonsensical, rude, and highly emotional, especially when discussing political issues (Papacharissi 2004, Brooks \& Geer 2007, Hmielowski et al. 2014). These uncivil expressions encourage the polarization of issues and affect others' perceptions over the stories surrounding a particular issue (Brooks \& Geer 2007, Anderson et al. 2013).

The issue of the online political debate in Indonesia increased rapidly on the eve of the 2019 National Election. The Indonesian 2019 legislative and presidential elections held on $17^{\text {th }}$ April 2019 were said to be the world's most complex poll, whereas many as 192 million people expected to vote at around 800.000 poll stations spread across the Indonesian archipelago (Temby et al. 2019). Various vital issues overshadowed the 2019 Indonesian election process such as economic issues, the track record of incumbent President Joko Widodo in terms of infrastructure development, the role of Islam in the political landscape, the emerging power of millennial voters, the increasing rate of internet penetration and the use of social media (Hefner 2018, Temby et al. 2019). The polarization atmosphere also overshadowed the 2019 presidential election, especially concerning the competing Islamic narratives between the two candidates. This competition is evident foremost in the split of the voter views on the quick count method carried out by several pollsters, although some of the previous research has focused on the relationship between civility and the decline of the public spheres and political discourse, the definition of civility itself is still considered to be unsatisfactory. According to Papacharissi (2004), civility often misunderstood when interpreted as general interpersonal decency. This argument came from the definition which ignores the essential democratic significance of a heated and passionate discussion. Interpersonal decency usually emphasizes compromise and attempts to avoid confrontation, whereas, in democracy, these two elements do not always have a positive effect.

To find out the extent of incivility that appears in the text, Papacharissi (2004) offers a definition of civility that can cover all elements, including the democratic aspect. Papacharissi (2004) stated, civility is a collective politeness, taking into account the democratic consequences of disrespectful behavior. Incivility is defined as a group of behaviors that threaten democracy, ignore the personal freedoms of others, and stereotype other social groups (Papacharissi 2004). Based on the definition above, Papacharissi (2004) developed an operational index to determine whether a comment violates democratic standards or, in other words, to determine if it contained incivility expressions. A commentary said to contain an incivility expression if 1 ) it contains a verbal threat to democracy, 2) it puts forward a stereotype of another party, and 3) it threatens the rights of others, including their freedom and freedom of speech. The second operational index was also offered by Papacharissi to see whether the comments showed a disrespectful expression or not. A comment is said to contain a disrespectful expression when it 1) contains name-calling, 2) contains an element that humiliates or disparage others (casting aspersion), 3) uses hyperbole, 4) accuses the other party of lying, 5) contains vulgarity, 6) gives off a non-cooperative signal and 7) contains sarcasm, as well as other disrespectful expressions that do not belong to any of the categories above. For example, this can include shouting remarks or talking loudly using uppercase letters throughout the text.

As explained earlier, the main normative concern about incivility and disrespectfulness is that it disrupts democratic societies (Benson 1996, Papacharissi 2004). One component of this disruptive effect is the possibility of uncivil and disrespectful expressions disrupting the public discussion, which will ultimately weaken the circulation of ideas. Any form of incivility can influence people's ability to participate in communication and political deliberation (Hardarker 2010, Sapiro \& Soss 2010). Incivility also tends to delegitimize political arguments and undermine the audience's evaluation capabilities (Brooks \& Geer 2007, Mutz 2007, Eveland \& Hively 2009). Incivility is also suspected of weakening political beliefs. Borah's study on political blogs shows that uncivil comments on political blogs reduce the reader's open-mindedness, on the other hand, it also increases the level of online participation (Borah 2014). 
In the Indonesian political landscape, initial anecdotal observations found that uncivil and disrespectful expressions arose exponentially on social media and online news outlets when both polar and partisan polar issues emerged. This research seeks to determine the extent to which uncivil and disrespectful expressions appear in the reader comments column in one of the most popular online news outlets in Indonesia, Detik.com, especially within the subject domain of polar and divisive political issues. This study will be focused on one of the most polar and divisive political issues during the 2019 Indonesian Presidential Election, namely the pollster's statistical data presented several hours after the election. All news articles with the \#quickcount hashtag label will be collected along with every comment that followed. These comments will be coded based on the coding scheme provided by Papacharissi (2004), which thoroughly distinguishes between incivility and disrespectfulness.

\section{Research Method}

In recent years, there has been considerable scholarly attention related to the internet's impact as a medium for use in the Indonesian political landscape, little known about how uncivil and disrespectful expressions appear in the Indonesian online political discussion. This study aims to start an interest in filling this critical gap in the existing literature. Ziegele \& Quiring (2013) introduced the term MediaStimulated Interpersonal Communication (MSIC) to describe online and offline conversations about media content. Forms of communication, such as reader comments on online news sites, should be labeled 'interpersonal' to emphasize the social and interactive character. Online reader comments are defined as the sub-categories of public, asynchronous, and computer-mediated MSICs published in the context of specific news items on websites of certain mass media organizations or within the services that are part of the media organization (Ziegele \& Quiring 2013). A series of online user comments associated with a particular news item defined as an online discussion.

The method used in this research is quantitative content analysis-Detik.com chosen for two reasons. First, Detik.com is the most popular news website with a monthly access total of around 8.7 million times (Morgan 2018). Second, Detik.com does not ask its readers to show their identity in the comments section. This system supports anonymity, meaning that newsreaders are freer to write what comments they like without fear of reprisal. This research data population is all of the readers' comments within all news articles associated with the \#quickcount hashtag label found on $18^{\text {th }}$ May 2019, a day after the 2019 Indonesian National Election. The population of comments collected from Detik.com totaled 403 collected from 15 news articles.

The comments were then coded one-by-one by two trained students based on the prepared coding scheme. Papacharissi (2004) developed an operational coding scheme to determine whether the comment violates a democratic standard or whether the word includes an uncivil expression. The comment is said to contain an incivility expression if it 1) contains a verbal threat to democracy, 2) stereotypes others, and 3) threatens the rights of others, including personal freedom and freedom of speech. Papacharissi (2004) also offered a second operational index in order to see if the comment showed a disrespectful expression. The comment is said to contain a disrespectful expression if it 1) contains name-calling, 2) casts aspersions, 3) uses hyperbole, 4) accuses the other of lying, 5) uses or contains vulgarity, 6) contains non-cooperative signals, and 7) contains sarcasm, as well as other disrespectful expressions that do not fall into any categories above. For example, this can include shouting remarks or speaking loudly with capital letters throughout the text.

\section{Results and Discussion}

Based on these research results, the uncivil expression did not appear significantly in the online reader comments of the total 403 comments examined, only 25 comments $(6.2 \%)$ contained at least one form of incivility (Table 1). These results align with the other studies conducted by Papacharissi (2004) \& Rowe (2014), which show a low number of uncivil expressions in online political discussion. As has been previously thought, disrespectful expressions are more common in the comments left by online users, on the other hand, disrespectful expression showed a too high number, of which 309 out of the 
total 403 coded comments $(76.7 \%)$ contained at least one form of disrespectful expression. Overall, the most common forms of disrespectful expressions are name calling $(23 \%)$, followed by hyperbole $(15,6 \%)$ and sarcasm $(6,2 \%)$.

The high rate of the expression of disrespectfulness in the comments affects the reader's ability to maintain the discussion's rationality. The discussions are often deficient coherent, where the discussion's focus deviates from the theme of the articles discussed earlier. There are at least two reasons why uncivil and disrespectful expressions can reduce the discussion's rationality and quality. First, as mentioned before, the expression of sarcasm, aspersions, and vulgarity creates an echo chamber where the commentators tend to leave comments with the same tone in either the approval or rejection of the ideas presented. Second, gradually the readers' comment section will ultimately be filled with uncivil and disrespectful expressions. This condition increases the feeling of isolation for the users who have a different opinion. In the comments section, the reader can evaluate the form and tendency of the discussions that occur. Any readers who want to voice their unique opinion, especially those who have opinions contrary to the majority, will feel isolated and reluctant to say anything. Therefore, the variation of opinions within online political discussions is relatively low. This situation is similar to Elizabeth Neuman's spiral of silence theory, where people with different opinions will likely be 'silent' out of the fear of isolation (Noelle-Neumann 1984). It is exacerbated by the 'like' appreciation system that appears in the comments. 'Likes' are equivalent to approval and for comments that have more likes, they are more approved and supported by other users. Within the context of the reader's comments, the isolated feeling of those with different opinions will be more pronounced because disrespectful expressions are mostly antagonistic and offensive. It causes the readers who dare to give a different opinion often have to 'defend themselves' by using the same strategy, which uses rude expressions. Ironically, this aspect of the 'defense mechanism' is evident in systems that use Facebook plug-ins because it causes anyone who activates Facebook 'like' the comments. In turn, it leads to a new hypothesis: the comments section shows a low level of expression of a lack of civility because the flow of the ideas and opinions appears to be limited to 'popular' opinions.

Table 1.

Codes for uncivil expressions found in theDetik.com reader comments

\begin{tabular}{lcc}
\hline \multicolumn{1}{c}{ Form of incivility } & \multicolumn{2}{c}{$\begin{array}{c}\text { Comments } \\
\text { from Detik.com }\end{array}$} \\
\cline { 2 - 4 } & f & $\%$ \\
\hline $\begin{array}{l}\text { Threat to democracy: Advocates overthrowing the government, begin } \\
\text { revolution, or suggesting an armed struggle in opposition to the government. }\end{array}$ & 3 & 0.74 \\
$\begin{array}{l}\text { Threat to personal rights: Advocates denying or restricting the rights of certain } \\
\text { individuals. }\end{array}$ & 4 & 1 \\
$\begin{array}{l}\text { Use of stereotypes: Asserts a widely held but oversimplified image of a particular } \\
\text { type of person or group. }\end{array}$ & 18 & 4.47 \\
\hline
\end{tabular}

The observation results show significant differences in the previous studies' results, especially those conducted by Papacharissi (2004) \& Rowe (2014). According to Papacharissi (2004), research conducted in several Usenet Newsgroups in the United States showed that most users express their opinions on political issues through a civilized and polite attitude. The discussion flow is much calmer and in a lighter tone. Usually, the initial comments will begin with a call for action, complaints, criticism, or references to famous public debates. The discussions will gradually increase to debate, and generally, they will decrease in intensity after a user comments in the form of an incivility or disrespectful expression. Usually, the debate will be ended by the users who come to understand that the discussion has arrived at the point of nonsensical rants. At this point, the users will often apologize to each other for their use of sarcasm and/or other forms of disrespectfulness. Although those who use incivility and disrespectfulness never apologize for what they have written, expressions of disrespectfulness seem to appear spontaneously in an unplanned and unintentional manner, and they usually regretted. It is different from the expression of incivility, which is usually more assertive and not regrettable. 
On the otherhand, the reader comments on Detik.com to show a more straightforward pattern. Most users will respond to comments on articles usually in the form of criticism, expressions of disappointment or anger, and appreciation if the user agrees with the issue raised. The discussion process follows the response of the other users who respond to the comments that have been given previously. One thing visible in the Indonesian online political discussion is the lack of decent and constructive discourse. An important reason why the level of expression of incivility and disrespectfulness is high is that users in Indonesia interpret the reader's comment section as a location for expressing their anger and disappointment. The majority of comments on Detik.com seem to appear in the form of harmful and hateful expressions. Civilized forms of discussion that prioritize logic and collectively find solutions are not found in the comments column on Detik.com. Almost all forms of conversation (where users reply to each other's comments) generally always contain disrespectfulness expressions. Disagreements over failure are rarely elaborated on in structured sentences, both in words and ideas. All expressions of incivility and disrespectfulness observed arose spontaneously, were unplanned, and not regretted.

Table 2.

Codes for disrespectful expressions found in theDetik.com reader comments

\begin{tabular}{lcc}
\hline \multicolumn{1}{c}{ Form disrespectfulness } & \multicolumn{2}{c}{$\begin{array}{c}\text { Comments from } \\
\text { detik.com }\end{array}$} \\
\cline { 2 - 3 } & $\mathbf{f}$ & $\%$ \\
\hline $\begin{array}{l}\text { Use of name calling: Clearly contains derogatory words towards the person it } \\
\text { is intended for }\end{array}$ & 93 & 23 \\
$\begin{array}{l}\text { Cast aspersions: Attacks the reputation or integrity of someone } \\
\text { Lie allegations: Implies disingenuousness like fraud, being a liar, dishonesty, } \\
\text { manipulation etc. }\end{array}$ & 6 & 1.5 \\
$\begin{array}{l}\text { Use of Vulgarity: Contains vulgar language like swear words, sexual innuendo } \\
\text { etc. }\end{array}$ & 15 & 5.7 \\
$\begin{array}{l}\text { Use of Hyperbole: Contains any form of exaggeration or massive overstatement } \\
\text { Non-cooperative stance: Any discussion that ends in a stalemate where no } \\
\text { parties are willing to listen }\end{array}$ & 63 & 15.6 \\
$\begin{array}{l}\text { Contains Sarcasm } \\
\text { Other disrespectful expressions that do not fall into any of the above categories: } \\
\text { Including shouting remarks using excessive capital letters and/or exclamation } \\
\text { marks }\end{array}$ & 25 & 0.5 \\
\hline
\end{tabular}

Source: Coding results

One crucial element that determines the difference in how users leave a comment is how the news site manages the comments section. This argument refers to discourse architecture, where virtual technology determines the discourse structure (Jones \& Rafaeli 2000). The user comments section varies in terms of including several features, such as how many comments are displayed on one page and how the comments sorted. News sites also display differences regarding the extent to which moderation will be carried out in the discussion or whether reader registration is needed for writing a comment (Singer et al. 2011, Ruiz et al. 2011). The most important aspect of discourse architecture is in terms of the account settings policies.

Detik.com has implemented a particular account system for its readers. Users are required to create a particular account in order to be able to navigate the site. It includes interacting with other users, commenting or contacting each other. The account registration uses Facebook and Google+ social media account plug-ins for anyone who wants to leave a comment. After the registration is complete, the user is free to fill in their data, displayed in the readers' comments section. This registration system has a very significant influence, namely, on the level of user anonymity. Such registration systems cannot force users to use their original name and identity, which provides users with high anonymity (Hermida \& Thurman 2007). News sites that directly integrate and display the information drawn from social media accounts are known to minimize user anonymity (Rowe 2014). One of the main 
features of social media networks, such as Facebook, is to paint an accurate picture of individual relationships and social activities. Facebook requires its users to construct public or semi-public profiles, so they can navigate the site. The users are encouraged to maintain a relatively open and identifiable profile, including posting photos and providing information about their date and place of birth, hobbies, education, and any religious and/or political affiliations. The profile also contains a space where other users can leave messages, provide links, and establish connections.

The user's network - including institutions, contacts, and friends - plays an essential role in their decision to communicate (Taylor et al. 2005). As a result, their online communicative behavior can vary depending on their perception of the group size and the individual's commitment to the group (Gangadharbatla 2008). Facebook users can be identified at once, and they can thus be held accountable for all of the content that they produce. The second reason is that Facebook users theoretically tend to be more reluctant to participate in communicative behavior that shows uncivil and disrespectful expressions. It is because their Facebook social network system will automatically be notified of the activities of the involved parties through the 'newsfeed' functions. Therefore, when one user leaves a comment using their Facebook account, this content will appear publicly not only to those who are participating in the same forum but also to those connected to them on the Facebook network. This form of 'pervasive awareness' (Hampton et al. 2011) among friends and colleagues significantly increases accountability; therefore, it has the potential to reduce the possibility of expression in a manner that is not civilized. In several studies (Rowe 2014, Halpern \& Gibbs 2013), a form of discourse architecture that minimizes anonymity can reduce the risk of expression of incivility and disrespectfulness.

Although uncivil expressions appear in small amounts, it does not mean that uncivil expressions are not a problem to watch out. The stereotypical expressions that appear in many comments are offensive and dangerous. Although a moderation system has been implemented and Detik.com requires its users to comply with its regulations to avoid offensive and rude comments, comments with offensive stereotypes are still found. From the observations, the users will tolerate different comments depending on their perceived affiliation of the article commented. For example, some users will tolerate more uncivil comments aimed at those who are perceived to be the 'enemies of Islam' (including President Jokowi, who was falsely accused of being a communist supporter and Chinese puppet) while at the same time accusing Detik.com of being a manipulative media outlet. This tolerance level for disrespectful expression is elastic and can change rapidly when discussing partisan and divisive issues. More in-depth research is needed to support this hypothesis, including research looking into developing expression trends concerning civilization year to year, on the other hand, disrespectful expressions are found in significant numbers. Referring to the disrespectfulness analysis units that examined, the use of name calling had the highest percentage (23\%) followed by hyperbole $(15,6 \%)$ and sarcasm $(6,2 \%)$. Sarcasm and name calling fall into the category of aggression (Ziegele \& Quiring 2013), which is often understood by ordinary users as the simplest form of disrespectfulness. When writing comments given by news sites, the rules are generally also limited to these three units of analysis, including stereotyped tones. Interestingly, sarcasm and name-calling were the most common within the boundaries of the common uncivil expressions. These results indicate that many online users do not comply, understand, and pay enough attention to the rules put in place by the news sites.

Comments that contain an aggressive tone can 'challenge' the norms and ideals of other users, which ultimately affects the social significance and position of the user, encouraging them to defend their opinion by responding to the comments. On the other hand, comments containing incivility and disrespectfulness are also suspected to be a barrier for further participation (Papacharissi 2004). Any comments that contain aggression also seem to help to create an 'echo chamber' within discussions where offensive comments will stimulate others to express responses in the same form. Offensive comments will generally be responded to with the same aggressive tone in the form of either an agreement or a rebuttal. It is likely to be why the high use of the sarcasm and name-calling in comments on the Detik.com news site. This result is also in line with the research conducted by Ziegele \& Quiring (2013), where the respondents stated that they would be more inclined to write aggressive sentences if the discourse architecture site supported anonymity. 
Allegations of lies also showed as having a high percentage. Accusations of lies, in general, can be divided into three points. The first is the accusation directed to the ruling regime, which is generally indicated by various allegations of manipulating the election results. Second, there are the accusations of forgery directed to any pollster that quickly displays the results of the election. The third lies accusation takes form in accusing Detik.com as untrustworthy and deceitful media because Detik. com displays the quick count results from various survey institutions. This result can be considered an indication that online users, to a certain extent, have strong perceived affiliations to the media that they read. They have a personal attitude formed before they read the news articles, meaning that if the news raised does not match the two variables above, then the news will be considered dishonest. This 'trust issue' seems to have increased dramatically since the debate over the issue of the election came to the fore, where whether or not the news is valid has become more prominent in the community. The column of reader comments seems to be a parameter regarding how the readers trust the media.

\section{Conclusions}

From the research results, it can be concluded that Indonesian online political discussions are rife with incivility and disrespectful expressions, primarily when the discussion focused on highly polar and divisive political issues. This understanding is expected to be a starting point to get a complete picture of how political discussions evolve in the online realm, especially in Indonesia. This research is also expected to start another study focusing on the impact of expressions of incivility and disrespectfulness on online discussions. To some extent, this research has successfully mapped the expression pattern of incivility and disrespectfulness found in the online user comments in Indonesia, which hopefully can be used as a starting point for more in-depth and more elaborate research into online political discussions in Indonesia.

\section{References}

Anderson AA, Brossard D, Scheufele DA, Xenos MA, \& Ladwig P (2013) The nasty effect: Online incivility and risk perceptions of emerging technologies. Journal of Computer-Mediated Communication 19 (3):373-387. https://doi.org/10.1111/jcc4.12009.

Benson TW (1996) Rhetoric, civility, and community: Political debate on computer bulletin boards. Communication Quaterly 44 (3):359-378. https://doi.org/10.1080/01463379609370023.

Borah P (2014) Does It matter where you read the news story? Interaction of incivility and news frames in the political blogosphere. Communication Research 41 (6):809-827.https://doi.org $/ 10.1177 / 0093650212449353$.

Brooks DJ \& Geer JG (2007) Beyond negativity: The effects of incivility on the electorate. American Journal of Political Science 51 (1):1-16. https://doi.org/10.1111/j.1540-5907.2007.00233.x.

Eveland WPJ \& Hively MH (2009) Political discussion frequency, network size, and heterogeneity of discussion as predictors of political knowledge and participation. Journal of Communication 59 (2):205-224. https://doi.org/10.1111/j.1460-2466.2009.01412.x.

Gangadharbatla H (2008) Facebook me: Collective self-esteem, need to belong, and internet selfefficacy as predictors of the igeneration's attitudes toward social networking sites. Journal of Interactive Advertising 8 (2):5-15. https://doi.org/10.1080/15252019.2008.10722138.

Halpern D \& Gibbs JL (2013) Social media as a catalyst for online deliberation? Exploring the affordances of Facebook and YouTube for political expression. Computer in Human Behavior 29 (3):1159-1168. https://doi.org/10.1016/j.chb.2012.10.008.

Hampton KN, Lee C, \& Her EJ (2011) How new media affords network diversity: Direct and mediated access to social capital through participation in local social settings. New Media and Society 13 (7):1031-1049. https://doi.org/10.1177/1461444810390342.

Hardarker C (2010) Trolling in asynchronous computer-mediated comunciation: From user discussions to academic definitions. Journal of Politeness Research 6 (2):215-242. https:// doi.org/10.1515/jplr.2010.011. 
Hefner RW (2018) The religious field: Plural legacies and contemporary contestations. In: Hefner RW (ed). Routledge Handbook of Contemporary Indonesia. New York: Routledge.

Hermida BA \& Thurman N (2007) Comments please: How the British news media are struggling with user-generated content. In: $8^{\text {th }}$ International Symposium on Online Journalism, 30-31 March, Austin. Austin: University of Texas, 1-28.

Hmielowski JD, Hutchens MJ, \& Cicchirillo VJ (2014) Living in an age of online incivility: Examining the conditional indirect effects of online discussion on political flaming. Information, Communication \& Society 17 (10):1196-1211. https://doi.org/10.1080/13691 18X.2014.899609.

Jones Q \& Rafaeli SF (2000) Time to split, virtually: Discourse architecture and community building create vibrant virtual. Electronic Markets 10 (4):214-223.

Morgan R (2018) Detikcom \& KOMPAS.com \& Liputan 6 are Indonesia's leading news websites. [Accessed 4 January 2020]. http://www.roymorgan.com/findings/7622-top-10-indonesiannews-websites-march-2018-201806172227.

Mutz DC (2007) Effects of "In-Your-Face" television discourse on perceptions of a legitimate opposition. American Political Science Review 101 (4):621-635. https://doi.org/10.1017/ S000305540707044X.

Noelle-Neumann E (1984) The Spiral of Silence: Public Opinion, Our Social Skin. Chicago: The University of Chicago Press.

Papacharissi Z (2004) Democracy online: Civility, politeness, and the democratic potential of online political discussion groups. New Media and Society 6 (2):259-283. https://doi.org/ $10.1177 / 1461444804041444$.

Rowe I (2014) Civility 2.0: A comparative analysis of incivility in online political discussion. Information, Communication \& Society 18 (2):121-138. https://doi.org/10.1080/1369118X. 2014.940365.

Ruiz C, Domingo D, Micó JL, Díaz-Noci J, Meso K, \& Masip P (2011) Public sphere 2.0? The democratic qualities of citizen debates in online newspapers. The International Journal of Press/Politics 16 (4):463-487. https://doi.org/10.1177/1940161211415849.

Sapiro V \& Soss JOE (2010) Spectacular politics, dramatic interpretations: Multiple meanings in the Thomas/Hill Hearings. Political Communication 16 (3):285-314. https://doi.org/ 10.1080/105846099198640.

Schaufele DA (2001) Democracy for some? How political talk both informs and polarizes the electorate. In: Hart RP \& Shaw DR (eds). Communication in U.S. Elections: New Agendas. Lanham: Rowman and Littlefield Publishers. 19-32.

Singer JB, Domingo D, Heinonen A, Hermida A, Paulussen S, Quandt T, Reich Z, \& Vujnovic M (2011) Participatory Journalism: Guarding Open Gates at Online Newspapers. UK: Blackwell Publishing Ltd.

Taylor SE, Peplau LA, \& Sears DO (2005) Social Psychology (12th ed). London: Pearson.

Temby Q, Burhani AN, \& Irawanto B (2019) Indonesia's 2019 elections: The key issues. Yusof Ishak Institute 30:1-8.

Ziegele M \& Quiring O (2013) Conceptualizing online discussion value: A multidimensional framework for analyzing user comments on mass-media websites. Annals of the International Communication Association 37 (1):125-153. https://doi.org/10.1080/23808985.2013.11 79148. 